\title{
CORRESPONDENCE
}

\section{A NEW FORCEPS FOR INTRACAPSULAR EXTRACTION OF CATARACT}

To the Editors of The British Journal of Ophthalmology.

SIRs,-It was rather amusing to me that while I was writing down some notes regarding the new use of an old forceps, in the operation of intra-capsular extraction of cataract, I read in the last number of the Journal (August, 1933) almost similar notes on the subject. I have not yet extracted as many cataracts with this forceps as has Mr. R. B. Ratnakar, and I was postponing the publication of these lines till I had operated on more cases.

The use, for the first time, of this forceps which I endeavour to describe now, occurred to me accidently, but further practice has approved its subsequent use.

Our historic Qalawoon Hospital (founded in 1284 A.D., long before the elaborate system of modern hospitals of the era of MacCallan), for a time previously staffed by distinguished oculists belonging to a French School, has amongst its instruments some very good French ones. The forceps above mentioned, belongs to this category of instruments. It is illustrated in Luer's catalogue under the. name of Pince à cuillers du Dr. Schmidt, and in the American Encyclopedia of Ophthalmology it is described (page 5263) as "Schmidt's Spoon Forceps, for the extraction of Lenticular Remains." In our hospital it is called the "Clot Forceps," and I always have it at hand for every intra-ocular operation.

In 1931, I brought with me from Vienna a Kalt forceps for extracting cataract in its capsule. I left it in the hospital for occasional use. Before leaving for the Congress in Madrid, 1933, 1 collected and took back to my private clinic the few instruments which I kept in hospital for my personal use. On resuming work I forgot to take with me to hospital the Kalt forceps. This I discovered while operating on a cataract and after the section was made. I attempt the intra-capsular method in every suitable case, and owing to the absence of the forceps reserved for this purpose, I ventured to try this so-called "clot forceps," and to my amazement the lens came out very easily and the operation

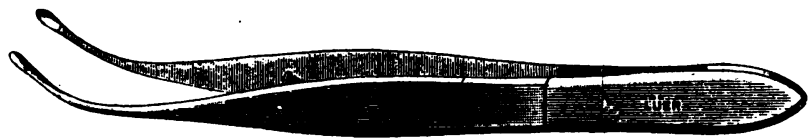


ended uneventfully. I am now using it instead of the Kalt forceps. The points to note about this forceps are the following:-

1. The extremities of the forceps end in spoon-like concavities which come in apposition all round the edge when the forceps is closed. In this way it differs from Mr. Ratnakar's forceps, in that the knuckle of capsule caught up by the forceps cannot be seen through the cornea being enclosed in the concavities.

2. The advantages of a forceps ending in such a hollowed fashion, either like Mr. Ratnakar's or the one I describe, is that the capsule tissue pressed between the two ends of the forceps, the greater part of which finds shelter or protection in the mentioned concavities, is less likely to be crushed or torn out, as it would be with a forceps whose ends meet in every point as is the case in Kalt's forceps.

3. The application of other capsule forceps curved to fit the anterior surface of the lens should be very dexterously done, more so than with this forceps which meets the lens in a smaller extent and so can grasp the lens where it meets it.

Yours truly,

15A, MADABEGH STREET, CAIRO.

M. KhaliL.

Yours truly,
M. KHaLIL.

\section{NOTES}

Mr. Arnold Sorsby has been elected HunAppointment terian Professor at the Royal College of Surgeons for 1933-34. He will deliver his lecture, the subject of which is Retinal Abiotrophy, on Monday, January 29,1934 , at 5 p.m.

The William Mackenzie
Medal tributions to ophthalmology, especially those bearing on the treatment of detachment of the retina. The presentation of the medal will be made in the hall of the Royal Faculty of Physicians and Surgeons, Glasgow, on Friday, October 13, at 8.30 p.m., when Professor Gonin will deliver the William Mackenzie Memorial Lecture on "The Evolution of Ideas concerning Retinal Detachment within the last five years." 